\title{
Parasitic castration, growth, and sex steroids in the freshwater bonefish Cyphocharax gilbert (Curimatidae) infested by Riggia paranensis (Cymothoidea)
}

\author{
Neuza R. W. Lima*, Juliana de S.Azevedo**, Leonardo G. da Silva***, \\ and Marilvia Dansa-Petretski***
}

Cyphocharax gilbert shows parasitic castration when infested by the crustacean Riggia paranensis, being unable to reproduce. Fish were sampled in the middle rio Itabapoana, Brazil, to study the prevalence of parasitism, growth, and sex steroid concentrations, considering the body size, sex, and reproductive condition of specimens. Most of the fish analyzed were infested (56.0\%). The presence of two lines on the scales was more frequent among infested fish (22.0\%) than among fish without parasites (12.0\% for females and $10.0 \%$ for males). The occurrence of three lines on the scales was rare (3.5\% among infested and 2.0\% among females without parasites). These results suggest that growth of the host is faster than that of non infested fish. The serum concentrations of sex steroids from fish without parasites varied at different gonadal development stages (17 beta-estradiol: 60.0 to $976.7 \mathrm{pg} / \mathrm{ml}$; total testosterone: 220.0 to $3,887.7 \mathrm{pg} / \mathrm{ml}$ ). All infested fish had lower levels of the two sex steroids and undeveloped gonads. Sex steroids levels in infested females were close to those in females at postspawning stages. Total testosterone concentrations of infested males were below those of males at early gonadal maturation stage. These results suggest that $R$. paranensis reduces the reproductive capacity of $C$. gilbert by affecting the host endocrine system.

Cyphocharax gilbert exibe castração parasitária quando está infestado pelo crustáceo Riggia paranensis, estando impossibilitado de reproduzir. Os peixes foram coletados no trecho médio do rio Itabapoana, Brasil, para analisar a prevalência do parasitismo, quantificar crescimento e as concentrações de esteróides sexuais, considerando o tamanho do corpo, o sexo e a condição reprodutiva dos espécimes. A maioria dos peixes analisados estava infestada (56,0\%). A presença de duas linhas em escamas foi mais freqüente entre os peixes infestados $(22,0 \%)$ que entre os peixes não infestados (12,0\% para as fêmeas e $10,0 \%$ para os machos). A presença de três linhas na escama foi rara (3,5\% entre os peixes infestados e 2,0\% entre as fêmeas não infestadas). Estes resultados sugerem que o crescimento no hospeideiro pode ser mais rapido que no peixes não parasitados. As concentrações de esteróides sexuais no soro dos peixes não infestados variaram entre os diferentes estágios reprodutivos (17 beta-estradiol: 60,0 a $976,7 \mathrm{pg} / \mathrm{ml}$; total testosterona: 220,0 a $3.887,7 \mathrm{pg} / \mathrm{ml}$ ). Todos os peixes infestados apresentaram baixos níveis dos dois hormônios esteroidais e ausência de desenvolvimento gonadal. Os níveis de esteróides sexuais nas fêmeas infestadas foram próximos aos níveis encontrados nas fêmeas pós-desovadas. A concentração de testosterona encontrada nos machos infestados foi inferior àquela obtida nos machos que estavam iniciando o desenvolvimento gonadal. Estes resultados sugerem que $R$. paranensis impede a reprodução de $C$. gilbert, afetando o sistema endócrino do hospedeiro.

Key word: Prevalence of parasitism, Scales lines, 17 Beta-estradiol, Total testosterone.

\footnotetext{
*Laboratório de Ecologia de Peixes, Departamento de Biologia Geral, Universidade Federal Fluminense, Niterói, RJ, Brazil.

**Laboratório de Nutrientes, Micro-nutrientes e Traços nos Ocenaos, Instituto Ocenaográfico, Universidade de São Paulo, 05.508-900 São Paulo, SP, Brazil.

***Laboratório de Química e Função de Proteínas e Peptídeos, Centro de Biociências e Biotecnologia, Universidade Estadual do Norte Fluminense, 28.015-620 Campos dos Goytacazes, RJ, Brazil.
} 


\section{Introduction}

Reproductive activities of hosts can be reduced or inhibited by their parasites, due to metabolic disturbances in somatic investments, sex determination, sexual behavior and population recruitments (Baudoin, 1975; Beckage, 1993; Thompson \& Kavalier, 1994; Arme 1997; Odonnell, 1997; Williams et al., 1998; Jobling \& Tyler, 2003; Hecker \& Kaerbe, 2005; Rice et al., 2006). The inhibitory effect of the isopod Riggia paranensis Szidat, 1948, a blood feeding parasite, on reproduction of the fish Cyphocharax gilbert (Quoy and Gaimard, 1824) has been described (Azevedo et al., 2002; Gomes da Silva et al., 2005; Azevedo et al., 2006). Like some species of family Cymothoidea, only females of $R$. paranensis are parasites. They growth inside a host-produced capsule in the pericardial area, maintain an opening in the host body to obtain the blood from gills and oxygen from the water, and deliver their brood into the environment (Raibaut \& Trilles, 1993). The males of $R$. paranensis are free-living specimens, being smaller than females. They live close to females inside C. gilbert specimens. Males can be found in a copulation position since they usually cling to the female near the bases of the pleopods (Bastos \& Thatcher, 1997).

The host $C$. gilbert is commonly found in coastal drainages of eastern Brazil and shows the highest fecundity among the members of the known Curimatidae (Azevedo et al., 1938; Vari, 1992; Azevedo et al., 2002). The populations of this species have a spawning period with two annual reproductive cycles of gonadal development, beginning in February and August and ending in June and December (Azevedo et al., 2002; Gomes da Silva et al., 2005; Azevedo et al., 2006). These fish were caught with signs of infestation by $R$. paranensis and showed an uncommon reproductive dysfunction in fish, usually observed in invertebrate hosts (Beckage, 1993; Sorensen \& Minchella, 2001) and called parasite castration (Baudoin, 1975). This author defined parasitic castration as "destruction or alteration of gonad tissue, reproductive behavior, hormonal balance, or other modification of the host reproductive effort above and beyond that which results from a nonselective use of host energy reserves by the parasite." The fitness of parasites could be increased due to increase in host survivorship growth and energy available to the parasite (Baudoin, 1975; Beck, 1980).

Cyphocharax gilbert infested by $R$. paranensis fail to undergo seasonal cycles of development and regression of gonads, and they resemble immature fish, irrespective of host size or sex (Azevedo et al., 2002; Gomes da Silva et al., 2005; Azevedo et al., 2006). The increase in host body weight, particularly in females, is one of physiological effects of parasitism on this fish (Azevedo et al., 2002), but growth of the host remained to be studied.

A remarkable feature of infested $C$. gilbert is the absence of two plasma sex-specific proteins besides the gonadal atrophy. The inhibition of gonadal development was observed in both males and females (Azevedo et al., 2002; Azevedo et al., 2006). The 33-kDa male-specific plasma protein and 143-kDa female-specific plasma protein are absent in infested fish (Gomes da Silva et al., 2005). The female-specific glycolipoprotein absent in C. gilbert infested by the isopod is a calcium-binding phosphoprotein composed of three polypeptides of 143,100 and $70 \mathrm{kDa}$ which seems to correspond to vitellogenin (Gomes da Silva et al. 2005). The concentration of the $143-\mathrm{kDa}$ plasma protein increases with the gonadal development of normal female fish. The absence of vitellogenin in the plasma of female hosts (Gomes da Silva et al., 2005) suggested that $R$. paranensis may affect the hormonal metabolism of $C$. gilbert.

Reproductive steroidal hormones regulate vitellogenesis and spermiogenesis in fish (Devlin \& Nagahama, 2002). In oviparous vertebrate females, the sex steroid 17 beta-estradiol is responsible for the stimulation of a calcium-binding phosphoprotein (vitellogenin) that is synthesized in the liver and released to the blood plasma (Schineider, 1996). This protein promotes the enlargement of oocytes, being their major constituent. The sex steroid testosterone is involved in fish male spermiation that involves the hydration of semen by increasing interlobular pressure, which allows the sperm to migrate to the vas deferens (Devlin \& Nagahama, 2002).

The objectives of this study were to examine the prevalence of parasitism and to determine if the parasite affects growth and serum concentrations of 17 beta-estradiol and total testosterone in males and females of $C$. gilbert.

\section{Materials and Methods}

Specimens of $C$. gilbert were monthly obtained by local fishermen in the middle rio Itabapoana (Rio de Janeiro/Espírito Santo states, southeastern Brazil; $21^{\circ} 15^{\prime} \mathrm{S}$ and $42^{\circ} 30^{\prime} \mathrm{W}$ ) from August, 1997 to July, 2000. Specimens were maintained in water collected from the river. The blood of each fish was collected one hour after capture. Before blood sampling, all fish were maintained for five minutes in cold water $\left(0^{\circ} \mathrm{C}, 5\right.$ $\min$.) to reduce sensitivity.

Sample blood was obtained from caudal vessel of fish with $5 \mathrm{ml}$ glass syringes without anti-coagulant. The coagulated blood samples were centrifuged at $1,800 \mathrm{~g}$ to separate the serum from blood cells. Serum was kept in ice during the transportation to the laboratory. To determine the concentration of hormone steroids, the fish serum samples and alkaline phosphatase-conjugated 17 beta-estradiol were simultaneously introduced into the Test Unit (Immulite System DPC - Diagnostic Products Corporations). The samples were coated with a polyclonal rabbit antibody specific for 17 betaestradiol and simultaneously introduced into the Test Unit, and incubated for approximately $60 \mathrm{~min}$ at $37^{\circ} \mathrm{C}$ with intermittent shaking. The same process was carried out for testosterone. The hormone assay was according to the Immulite operator's manual (DPC - Diagnostic Products Corporation, 
USA). The data did not display a normal distribution, and thus, non-parametric tests were used. The variation of hormonal concentrations among the three years and among gonadal and developmental stages of each sex was analyzed by the Kruskal-Wallis test (Snedecor \& Cochran, 1971). The variation in concentrations between the two reproductive periods (from August to January and from February to July) was analyzed by the Mann-Whitney U test (Snedecor \& Cochran, 1971), grouping the data obtained during the three years of study for males and females.

After blood collection, fish were maintained in cold water $\left(0^{\circ} \mathrm{C}, 5 \mathrm{~min}\right.$.). The standard body size of the fish was measured as the length from the tip of snout to the fork of caudal fin. The specimens were sacrificed by decapitation and opened to identify their sex by ovarian and testicular morphological characteristics (position, color, and size of gonads besides the presence of veins, eggs and sperm, as described by Menezes (1994); Vazzoler (1996); Azevedo et al. (2002). The relationship between morphological and histological characteristic of gonads was evaluated, following Menezes (1994). Parasitism causes significant damage to the fish gonadal development (Gomes da Silva et al., 2005). The damage is extensive but position and morphology of non-developed gonads of infected fish plus the similarity of normal specimens at initial gonadal development helped to make distinction between infested males and females (Azevedo et al., 2002 Azevedo et al., 2006). The infested fish were considered mature by their body size and number of lines of scales (Azevedo, 2002).

The fish were analyzed recording the sex, the gonadal development stages (initial early or advanced maturation, post-spawning, or inhibited development) (Azevedo et al., 2002; Azevedo et al., 2006), and the parasitic conditions (without parasitism signs or infested with one or two parasites). Fish with one or two empty perforations without parasites (Azevedo et al., 2006) were not involved in the present study due to the low frequency in the population (Azevedo et al., 2006). The prevalence of parasitism was calculated as the number of infested fish/number of fish examined x 100\%, according to Bush et al. (1997). The scales located in the axial part of the pectoral fins of $C$. gilbert are thin and show symmetry and low regeneration rate (Azevedo, 2002). Ten to fifteen scales were removed from 240 females and 226 males of non-infested fish, and from 162 males and 160 females of infested fish, washed in water to remove the epithelium and preserved in $70 \%$ ethanol. The scales were stained with red Alizarin solution ( $0.6 \%$ ) for $5 \mathrm{~h}$ and placed between to slides to count concentric lines without interruptions, according to Ambrósio \& Hayashi (1997). Correlation (r) tested if standard body length of fish (males, females or infested ones) were significantly related to the number of concentric lines on the scales (Snedecor \& Cochran, 1971). The variation in the number of concentric lines in scales among females, males and infested specimens (females and males) was determined by non-parametric analysis of variance, using the KruskallWallis test and Mann-Whitney U test (Snedecor \& Cochran, 1971) to see if sex or infestation condition affected the data. The number of concentric lines on scales was used to estimate fish growth according to Ambrósio \& Hayashi (1997).

Four specimens of $C$. gilbert infested with $R$. paranensis were deposited at Coleção Zoológica Didática, Universidade do Norte Fluminense (UENF/CY 1998/01-04). Vouchers were deposited at Museu Nacional do Rio de Janeiro (MNRJ 30982).

\section{Results}

A total of 1,038 fish were analyzed. The parasite prevalence was $56.0 \%$ among the collected fish. Most of the fish $(44.0 \%)$ were infested by only one parasite. The prevalence of two parasites was low (12.0\%). Body length of $C$. gilbert varied from $80 \mathrm{~mm}$ to $220 \mathrm{~mm}$. Standard body length of infested fish was not significantly different from that of fish without parasites $(P>0.05)$. Prevalence of parasitism and standard body length of host was not related. A similar proportion between male and female without parasites (M:F) was observed (49M:51F, $\mathrm{n}=454)$. The same pattern was observed among infested fish with one (48M:52F, $\mathrm{n}=440$ ) or two parasites (47M:53F, $\mathrm{n}=144)$.

Sex ratio for number of concentric lines on scales was similar among infested fish (49M:51F, $\mathrm{n}=332)$ or among fish without parasites (48M:52F, $\mathrm{n}=466$ ). Number of concentric lines on scales was similar among infested females and males. Thus, the data for them were grouped (Table 1). Most of the fish without parasites ( $51.0 \%$ of females, $56.0 \%$ of males) did not have any concentric lines on scales (Table 1). Among infested fish, $34.0 \%$ of them did not have theses lines. Fish with one line on scales varied from $34.0 \%$ (males without

Table 1. Frequency of individuals (\%) for each class of number of scale lines, the mean and standard deviation (+/- SD) of standard length $(\mathrm{cm})$ of Cyphocharax gilbert females and males without parasites and infested individuals. All specimens were collected from August, 1999 to July, 2000 in the middle rio Itabapoana, Brazil.

\begin{tabular}{ccccc}
\hline Fish & Scale lines & $(\%)$ & \multicolumn{2}{c}{ Standard length $(\mathrm{cm})$} \\
\cline { 3 - 5 } & & & Mean & $(+/-\mathrm{SD})$ \\
\hline Females & 0 & 51.0 & 12.78 & 1.41 \\
(without & 1 & 35.0 & 13.18 & 2.04 \\
parasites) & 2 & 12.0 & 13.88 & 1.94 \\
(n=230) & 3 & 2.0 & 14.50 & 0.51 \\
& & & & \\
Males & 0 & 56.0 & 12.60 & 1.71 \\
(without & 1 & 34.0 & 12.61 & 2.73 \\
parasites) & 2 & 10.0 & 13.47 & 1.42 \\
(n=236) & 3 & 0 & - & - \\
& & & & \\
Infested & 0 & 34.0 & 12.61 & 1.792 \\
(females + & 1 & 40.5 & 13.99 & 1.78 \\
males) & 2 & 22.0 & 14.31 & 2.56 \\
(n=332) & 3 & 3.5 & 15.00 & 0.85 \\
\hline
\end{tabular}


parasites) to $40.5 \%$ (infested males). Two lines on scales were more frequent among infested fish (22.0\%) than among those without parasites (12.0\% for females and $10.0 \%$ for males). Few fish displayed three lines on scales, but most of them were infested (3.5\%). The number of concentric lines on scales was significantly related to the increase in standard body length of fish (females: $r=0.41, \mathrm{n}=230 ; P £ 0.05$; males: $r=$ $0.36, \mathrm{n}=236, P £ 0.05$; infested: $r=0.37, \mathrm{n}=332 ; P £ 0.05)$. The variation in the number of concentric lines in scales among infested and non-infested fish (females plus males) was significant $(H=6.3 ; \mathrm{n}=798 ; d . f .=2 ; P £ 0.05)$. In non-infested fish, the number of lines found on scales of males was similar to the number observed in females $(Z=1.15 ; \mathrm{n}=466 ; d . f .=1 ; P$ $£ 0.05)$. The number of lines in infested fish was significantly different from that of non-infested fish (males plus females) without parasites $(Z=2.48 ; \mathrm{n}=798 ;$ d.f. $=1 ; P £ 0.05)$.

The analyses of gonads confirmed that all infested fish lacked gonadal development. Their gonads resembled those of fish at initial maturation, irrespective of host size or sex. Fish without parasites showed regular gonads at all stages of

Table 2. Mean concentration $(\mathrm{pg} / \mathrm{ml})$ and standard deviation $(+/-\mathrm{SD})$ of 17 beta-estradiol in non-infested females of $C y$ phocharax gilbert in different gonadal development stages and in infested females $(*)$ from rio Itabapoana, Brazil, collected from August 1997 to July 2000.

\begin{tabular}{cccccc}
\hline Gonadal & \multicolumn{3}{c}{ Reproductive periods of the year } \\
\cline { 2 - 3 } \cline { 5 - 6 } Development & \multicolumn{2}{c}{ August - January } & & \multicolumn{2}{c}{ February - July } \\
\cline { 2 - 3 } Stages & Mean & $(+/-$ SD) & & Mean & $(+/-$ SD) \\
\hline Initial Maturation & 65.5 & $(23.9)$ & & 60.4 & $(23.9)$ \\
(n) & $(21)$ & & & $(23)$ & \\
Early Maturation & 248.0 & $(16.0)$ & & 218.0 & $(16.0)$ \\
(n) & $(18)$ & & & $(22)$ & \\
Advanced Maturation & 920.0 & $(258.8)$ & & 976.7 & $(258.8)$ \\
(n) & $(20)$ & & & $(20)$ & \\
Post-spawning & 94.4 & $(22.5)$ & & 98.0 & $(22.5)$ \\
(n) & $(12)$ & & & $(15)$ & \\
Inhibited & & & & & \\
Development* & 76.9 & $(17.5)$ & & 64.9 & $(17.5)$ \\
(n) & $(19)$ & & & $(22)$ & \\
\hline
\end{tabular}

Table 3. Mean concentration $(\mathrm{pg} / \mathrm{ml})$ and standard deviation (+/- SD) of 17 beta-estradiol in non-infested males of Cyphocharax gilbert in different gonadal development stages and in infested.

\begin{tabular}{cccccc}
\hline Gonadal & \multicolumn{3}{c}{ Reproductive periods of the year } \\
\cline { 2 - 3 } \cline { 5 - 6 } Development & \multicolumn{2}{c}{ August - January } & & \multicolumn{2}{c}{ February - July } \\
\cline { 2 - 3 } \cline { 5 - 6 } Stages & Median & $(+/$ - SD) & & Median & $(+/-$ SD) \\
\hline Initial Maturation & 69.0 & $(16.3)$ & & 79.0 & $(21.4)$ \\
(n) & $(22)$ & & & $(17)$ & \\
Early Maturation & 60.0 & $(16.5)$ & & 72.8. & $(22.8)$ \\
(n) & $(18)$ & & & $(19)$ & \\
Advanced Maturation & 315.6 & $(57.1)$ & & 280.0 & $(42.1)$ \\
(n) & $(20)$ & & & $(21)$ & \\
Inhibited & & & & & \\
Development* & 75.7 & $(18.7)$ & & 71.2 & $(23.5)$ \\
(n) & $(20)$ & & & $(21)$ & \\
\hline
\end{tabular}

maturation, representing $44 \%$ of population. Post-spawning females were captured in the study area, but post-spawning males were not found.

Sex steroid concentrations (17 beta-estradiol and total testosterone) were determined in fish without parasites and infested fish with one or two parasites. The serum concentrations of 17 beta-estradiol in females without parasites increased with gonadal development, during the two reproductive periods of year (August to January and February to July) (Table 2). The mean concentration of 17 beta-estradiol was low in infested and non-infested females, at initial gonadal development and post-spawning stage, and high from early to advanced maturation. The variation of this steroid was not affected in the same manner in males (Table 3). The mean concentration of 17 beta-estradiol in females at early and advanced maturation of gonads were three times higher than in males at the same gonadal stage (Table 2 and 3). The mean concentration of total testosterone in females without parasites increased at early and advanced maturation of gonads (Table 4). Males without parasites showed the highest con-

Table 4. Mean concentration $(\mathrm{pg} / \mathrm{ml})$ and standard deviation $(+/-\mathrm{SD})$ of total testosterone in non-infested females of $C y$ phocharax gilbert in different gonadal development stages and infested females $(*)$ from rio Itabapoana, Brazil, from August, 1997 to July, 2000.

\begin{tabular}{cccccc}
\hline Gonadal & \multicolumn{3}{c}{ Reproductive periods of the year } \\
\cline { 2 - 3 } \cline { 5 - 6 } Development & \multicolumn{2}{c}{ August - January } & & \multicolumn{2}{c}{ February - July } \\
\cline { 2 - 3 } \cline { 5 - 6 } Stages & Median & $(+/-$ SD) & & Median & $(+/-$ SD) \\
\hline Initial Maturation & 220.0 & $(73.9)$ & & 287.7 & $(93.9)$ \\
(n) & $(21)$ & & & $(23)$ & \\
Early Maturation & 1993.1 & $(205.0)$ & & 1887.3 & $(216.0)$ \\
(n) & $(18)$ & & & $(22)$ & \\
Advanced Maturation & 3887.7 & $(358.8)$ & & 3600.8 & $(458.8)$ \\
(n) & $(20)$ & & & $(20)$ & \\
Post-spawning & 504.0 & $(98.5)$ & & 448.2 & $(99.5)$ \\
(n) & $(12)$ & & & $(15)$ & \\
Inhibited & & & & & \\
Development* & 609.3 & $(152.5)$ & & 506.7 & $(179.5)$ \\
(n) & $(19)$ & & $(23)$ & \\
\hline
\end{tabular}

Table 5. Mean concentration $(\mathrm{pg} / \mathrm{ml})$ and standard deviation $(+/$ - SD) of total testosterone in non-infested males of Cyphocharax gilbert in different gonadal development stages and infested males (*) fromrio Itabapoana from August, 1997 to July, 2000.

\begin{tabular}{cccccc}
\hline Gonadal & \multicolumn{3}{c}{ Reproductive periods of the year } \\
\cline { 2 - 3 } \cline { 5 - 6 } Development & \multicolumn{2}{c}{ August - January } & & \multicolumn{2}{c}{ February - July } \\
\cline { 2 - 3 } \cline { 5 - 6 } Stages & Median & $(+/-$ SD) & & Median & $(+/-$ SD) \\
\hline Initial Maturation & 470.0 & $(102.0)$ & & 430.5 & $(149.4)$ \\
$(\mathrm{n})$ & $(20)$ & & & $(17)$ & \\
Early Maturation & 3010.3 & $(970.5)$ & & 2280.8 & $(870.8)$ \\
$(\mathrm{n})$ & $(19)$ & & & $(25)$ & \\
Advanced Maturation & 586.0 & $(129.7)$ & & 502.1 & $(187.9)$ \\
$(\mathrm{n})$ & $(20)$ & & & $(23)$ & \\
Inhibited & & & & & \\
Development* & 420.2 & $(130.7)$ & & 460.4 & $(153.5)$ \\
$(\mathrm{n})$ & $(25)$ & & & $(22)$ & \\
\hline
\end{tabular}


centrations of total testosterone during early maturation of gonads (Table 5). Infested fish of both sexes showed low concentration of total testosterone when compared to fish with gonads at early or advanced maturation (Table 4 and 5).

The serum concentrations of 17 beta-estradiol and total testosterone in fish of each sex were not significantly different $(P>0.05)$ among the three analysed years (August 1997 to July 2000) or between the two reproductive periods of the year (August to January and February to July). Thus, the data were analyzed all together to test if the concentrations of each sex steroid were significantly different among the gonadal development stages for each sex separately.

Females at different gonadal development stages showed a significant variation in serum concentrations of 17 betaestradiol $(H=18.9 ; \mathrm{n}=192 ; d . f=4 ; P £ 0.05)$. Variation in the serum concentrations of 17 beta-estradiol in males at different gonadal stages was not significant $(H=2.5 ; \mathrm{n}=158 ; d . f=$ 3; $P>0.05)$. Significant differences were observed for the absolute serum total testosterone concentrations among females $(H=12.8 ; \mathrm{n}=193 ; d . f=4 ;, P £ 0.05)$ and among males $(H=11.6 ; \mathrm{n}=171 ; d . f=3 ; P £ 0.05)$. The 17 beta-estradiol levels in infested females were not significantly different $(P>$ 0.05 ) from that of females at initial maturation and post-spawning stages (Table 2). Levels of total testosterone in infested females were also similar to that of females at initial maturation and post-spawning stages (Table 4$)(P>0.05)$. Levels of total testosterone in infested males were also similar to that of males at initial maturation (Table 5) $(P>0.05)$.

\section{Discussion}

The present study showed that $56 \%$ of specimens of $C$. gilbert from rio Itabapoana were infested by one or two specimens of $R$. paranensis, confirming previous studies (Azevedo et al., 2002; Gomes da Silva et al., 2005; Azevedo et al., 2006). The prevalence of parasitism was not related to standard body length or sex of host, as described before (Azevedo et al., 2006). Environmental conditions could affect the spatial structure of the host population, increasing the prevalence of parasite and metabolic damage in the host (Grosholz \& Ruiz, 1995; Carvalho et al., 2003; Carvalho et al., 2004; Rajkumar et al., 2005). The high prevalence of parasitism in the study area was not observed in other areas (Azevedo et al., 2002). Such infestation pattern could be related to the susceptibility of host infection (Hurd, 2001; Kalbe \& Kurtz, 2006) or can be a secondary impact of the introduction of exotic fish species from rio Paraná into the rio Itabapoana (Bizerril \& Lima, 2001; Azevedo, et al., 2002), since $R$. paranensis was first observed in fish from Paraná basin, infesting Cyphocharax voga (Szidat, 1948).

A significant relation between standard length and the number of lines on scales was observed in the present study. The relation between size of fish and scale markers of growth are usually significant (Soriguer et al., 2000; Lysney et al.,
2006). The presence of two or three lines on scales was more frequent among infested fish than among fish without parasites in the studied area. The results of number of lines on scales of $C$. gilbert suggest that parasitism prolongs the life of the host, similar to that observed in the salmon Salmo salar infested by the mussel Margaritifera margaritifera (Ziuganov, 2005).

The parasite-induced castration and variation in host growth and longevity have been shown in several taxa and discussed in the light of changes in resource allocation from reproduction to growth, involving castration or reduction of host reproductive investment (Beckage, 1993; Kover, 2000; Kube et al., 2006; Rice et al., 2006). The adaptive advantage of this type of parasitism has been discussed to enable an ecological and evolutionary evaluation of host responses. Parasitic castration may promote variation in direct reproductive and somatic investment value within a host population, creating a division of reproductive labor among members (Kover, 2000; Sorensen \& Minchella, 2001; Lysne et al., 2006). The pathogen can manipulate the host to redirect resources away from reproduction and toward maintenance through castration, causing an increase in size (Bonds, 2006). The cod Gadus morhua infested by the gill copepod Lernaeocera branchialis showed the highest rate of increase, both in body mass and in body length. The observed difference in growth in this fish was associated with the resistance to the parasite rather than changes in reproductive strategies (Lysne et al., 2006). Previous studies showed that the physiological effects of $R$. paranensis on the fish $C$. gilbert are the significant increase in body weight in infested females, inhibition of gonadal development, and the absence of two plasma sexspecific proteins in both sexes (Azevedo et al., 2002, Gomes da Silva et al., 2005; Azevedo et al., 2006).

Infested $C$. gilbert lacked gonadal development and showed a low serum concentration of 17 beta-estradiol and total testosterone. Sex steroid concentrations in fish serum varied during the reproductive cycle among males or females without parasites, being related to their gonadal development stages. Infested fish fail to undergo seasonal cycles of development and regression, and they resemble immature fish. In the analyzed areas, non-infested females displayed four gonadal development stages, while non-infested males showed three stages (Azevedo et al., 2002; Gomes da Silva et al., 2005; Azevedo et al., 2006). The low frequency of postspawning females and the absence of males at this reproductive stage in the studied area strongly suggest that this phase is very short (Gomes da Silva et al., 2005). A different pattern was observed in the rio Paraíba do Sul (Menezes, 1994), a nearby south area.

The two sex steroid (17 beta-estadiol and total testosterone) concentrations in $C$. gilbert were very similar between the two reproductive periods in the population in the rio Itabapoana. The serum concentrations of testosterone in noninfested females were higher than the concentration of 17 
beta-estadiol. Changes in steroid synthesis during gonadal maturation in females are mediated in part by a reduction in the amount of ovarian aromatase, causing reduced conversion of testosterone to estradiol (Trant et al., 1997; Devlin \& Nagahama, 2002). It has been shown in fish females under culture conditions that androgen steroids can induce vitellogenin production and reduce serum estradiol levels, to increase gonadotropin secretion and to maintain sexual behavior (Devlin \& Nagahama, 2002).

All infested fish of both sexes had lower sex steroid concentrations compared to the non-infested specimens at early or advanced gonadal maturation stages. A similar average concentration of 17 beta-estadiol between infested males and those non-infested at early gonadal maturation stage was an exception to this pattern. In vitro analyses showed that low levels of 17 beta-estradiol synthesis occur in male rainbow trout even further at the onset of maturation (Vizziano et al., 1996; Devlin \& Nagahama, 2002).

The low sex steroid concentrations in infested fish suggest that $R$. paranensis affects the endocrine mechanism, reducing the 17 beta-estradiol and testosterone levels. The sex steroid 17 beta-estradiol acts at the level of the gonad to directly stimulate oocyte development and indirectly to control the expression of genes in several tissues involved in oocyte growth. Testosterone has anabolic effects by increasing appetite, food conversion efficiency and digestive functions (Devlin \& Nagahama, 2002; Syaghalirwa et al., 2005).

The effects of parasite on the levels of testosterone in $C$. gilbert may also be related to metabolism as reported in infected wild bream (Hecker \& Kaerbe, 2005). Immature ovaries and testes are still present in infested $C$. gilbert. Thus, the parasite may act on the brain-pituitary-gonadal axis of the fish to inhibit further development of reproductive organs. For example, the inhibition of LH expression and puberty in its teleost host, Rutilus rutilus, involve cytological changes in the gonadotrophs of the pituitary gland, and an inhibition of gonadal development, reflecting a significant and measurable effect of Ligula intestinalis on the pituitary gland. The metabolic products released from the parasite may interact with the brain-pituitary-gonadal axis of the fish host and thus inhibit gonadal development (Arme, 1997; Carter et al., 2005).

The inhibition mechanism of gonad development in $C$. gilbert is unknown but may involve several components of the parasite. The parasites can release neuropeptides, cytokine-like molecules or hormones that affect pituitary gland function, sexual behavior, sexual differentiation and reproductive capacity of the population (Beckage, 1993; Jobling \& Tyler, 2003; Carter et al., 2005; Hecher \& Karbe, 2005). However, the effect of parasitism on reproduction may be strongly related to the host reaction to the infection, rather than to a hormone or other signal released by the parasite (Hurd, 2001; Kalbe \& Kurtz, 2006). The immunocompetence of C. gilbert against the parasite is currently under study.

Parasites per se may not cause reproductive disturbances in the host (Lafferty \& Kurtis, 1999). Effects of both pollution and infestation was shown to have a serious impact on the reproductive capacity of the fish Abramis brama from the Elbe River, by reducing gonadal development and the plasma concentrations of vitellogenin, 17 beta-estadiol and testosterone. Distinct regional differences affected both the prevalence of parasite and A. brama reproductive capacity (Hecker $\&$ Kaerbe, 2005). However, the regional differences in the prevalence of $R$. paranensis on host population did not affect the parasite castration effects on $C$. gilbert so far. All infested $C$. gilbert collected in both high prevalence (rio Itabapoana) or low prevalence (de Cima and Feia Lagoons) areas did not exhibit gonadal development or sex-specific proteins (Azevedo et al., 2002; Gomes da Silva et al., 2005). In rio Itabapoana, the parasite $R$. paranensis infested around $60 \%$ of $C$. gilbert and did not show preference for body size or sex (Azevedo et al., 2006). This parasitism caused an increase in growth (present study) and body weight (especially in infested females) (Azevedo et al., 2002) and the reduction of 17 beta-estadiol and total testosterone levels in both infested males and females (present study), and the absence of plasma vitellogenin in infested females and of an unknown protein $(33 \mathrm{kDa})$ in infested males (Gomes da Silva et al., 2005). The parasite may inhibit the reproduction of $C$. gilbert by affecting its endocrine system.

\section{Acknowledgments}

We thank all the institutions (CNPq, FAERJ, UENF, UERJ, and UFF) and individuals who contributed to this study, in particular Antônio Carlos Pessanha and Luis Sérgio do Nascimento for assistance with various aspects of the study.

\section{Literature Cited}

Ambrósio, A. M. \& C. Hayashi. 1997. Idade e crescimento de Steindachnerina insculpta (Fernandez-Yepes, 1948) (Characiforme, Curimatidae) da planície de inundação do alto rio Paraná, Brasil. Revista Brasileira de Biologia, 57, 687-698.

Arme, C. 1997. Ligula intestinalis: Interaction with the pituitarygonadal axis of its fish host. Journal of Helminthology, 71:8384.

Azevedo, J. S. 2002. Dinâmica da interação parasito-hospedeiro entre Riggia paranensis (Szidat, 1948) (Crustacea, Cymothoidae) e Cyphocharax gilbert (Quoy e Gaimard, 1824) (Teleostei, Curimatidae), no rio Itabapoana, RJ/ES e considerações sobre a biologia reprodutiva do parasito. Unpublished MSc. Dissertation, Universidade Estadual do Norte Fluminense, Campos dos Goytacazes, Rio de Janeiro. 111p.

Azevedo, P. de, M. V. Dias \& B. B. Vieira. 1938. Biologia do sagüiru. Memórias do Instituto Oswaldo Cruz, 33:481-559.

Azevedo, J. S., L. Gomes da Silva, C. R. S. Bizerril, M. A. DansaPetretski \& N. R. W Lima. 2006. Infestation pattern and parasitic castration of the crustacean Riggia paranensis (Crustacea, 
Cymothoidea) on the fresh water fish Cyphocharax gilbert (Teleostei, Curimatidae). Neotropical Ichthyology, 43:363-369.

Azevedo, J. S., M. P. M. Thomé, L. Gomes da Silva, R. Novelli, M. A. Dansa-Petretski \& N. R. W. Lima. 2002. Parasitismo de Riggia paranensis (Crustacea, Cymothoidea) em populações de Cyphocharax gilbert (Teleostei, Curimatidae) do norte do Estado do Rio de Janeiro. Boletim do Instituto de Pesca, 28:61-69.

Bastos, P. B. \& V. E. Thatcher, 1997. A redescription of Riggia paranensis Szidat, 1948 (Isopoda, Cymothoidae) based on thirty-two specimens from Curimatid fish of Rio de Janeiro, Brazil, with an emendation of the genus. Memórias do Instituto Oswaldo Cruz, 92, 755-760.

Baudoin, M. 1975. Host castration as a parasitic strategy. Evolution, 29:335-352.

Beck J. T. 1980. Effects of an isopod castrator, Probopyrus pandalicola, on the sex characters of one of its Caribbean shrimp hosts, Palaemonetes paludosus. Biological Bulletin, 158: 1-15.

Beckage, N. E. 1993. Endocrine and neuroendocrine host-parasite relationships. Receptor, 3:233-245.

Bizerril, C. R. S. F. \& N. R. W. Lima. 2001. Espécies de peixes introduzidas nos ecossistemas continentais do estado do Rio de Janeiro. Comunicações do Museu de Ciências e Tecnologia, PUCRS, 14:43-59.

Bonds, M. H. 2006. Host Life-History Strategy Explains PathogenInduced Sterility. The American Naturalist, 168: 281-293.

Bush, A. O., K. D. Lafferty, J. M. Lozt \& A. W. Shostak. 1997. Parasitology meets ecology on terms, Margolis et al., Revisited. Journal of Parasitology, 83:575-583.

Carter, V., R. Pierce, S. Dufour, C. Arme \& D. Hoole. 2005. The tapeworm Ligula intestinalis (Cestoda : Pseudophyllidea) inhibits LH expression and puberty in its teleost host, Rutilus rutilus. Reproduction, 130:939-945.

Carvalho, L. N., R. Arruda \& K. Del-Claro 2004. Host-Parasite interactions between the piranha Pygocentrus nattereri (Characiformes, Characidae) and isopods and branchiurans (Crustacea) in the rio Araguaia basin, Brazil. Neotropical Ichthyology, 2: 93-98.

Carvalho, L. N., K. Del-Claro \& R. M. Takemoto. 2003. Hostparasite interaction between branchiurans (Crustacea: Argulidae) and piranhas (Osteichthyes: Serrasalminae) in Pantanal wetland of Brazil. Environmental Biology of Fishes, 67: 289-296.

Devlin, R. H. \& Y. Nagahama. 2002. Sex determination and sex differentiation in fish: an overview of genetic, physiological, and environmental influences. Aquaculture, $208: 191-364$.

Gomes da Silva, L., J. S. Azevedo, M. A C. Silva Neto, N. R. W. Lima \& M. A. Dansa-Petretski. 2005. Effect of the parasitism on sex-specific plasmatic proteins of Cyphocharax gilbert (Teleostei). Parasitology, 130:653-659.

Hecker, M. \& L. Kaerbe. 2005. Parasitism in fish - an endocrine modulator of ecological relevance? Aquatic Toxicology, 72:195207.

Hurd, H. 2001. Host fecundity reduction: a strategy for damage limitation? Trends in Parasitology, 17:363-368.

Jobling, S. \& C. R. Tyler. 2003. Endocrine disruption, parasites and pollutants in wild freshwater fish. Parasitology, 126:103-108.

Kalbe, M \& J. Kurtz. 2006. Local differences in immunocompetence reflect resistance of sticklebacks against the eye fluke Diplostomum pseudospathaceum. Parasitology, 132:105-116.

Kover, P. X. 2000. Effects of parasitic castration on resource allocation. Oecology, 123:48-56.
Kube, S., J. Kube \& A. Bick. 2006. Loss of fecundity in a population of mudsnail Hydrobia ventrosa caused by larval trematodes does not measurably affect host population equilibrium level. Parasitology, 132: 725-732.

Lafferty, K. D. \& A. M Kurtis. 1999. How environmental stress affects the impact of parasites? Limnology and Oceanography, 44:925-931.

Lysne, D. A., W. Hemmingsen \& A. Skorping. 2006. Is reduced body growth of cod exposed to the gill parasites a cost of resistance? Journal of Fish Biology, 69:1281-1287.

Marks, R. E., F. Juares, J. A Hare, \& D. O. Conover. 1996. Occurrence and the effect of the parasitic isopod, Lironeca ovallis (Isopoda: Cymothoidae), on young-of-the-year bluefish, Pomatomus saltatrix (Pisces: Pomacentridae). Canadian Journal of Fisheries and Aquatic Sciences, 53:2052-2057.

Menezes, M. S. 1994. Estrutura populacional e reprodução de Cyphocharax gilbert (Quoy \& Gaimard, 1824) (Osteichthyes, Curimatidae) no trecho inferior do rio Paraíba do Sul (RJ, MG) e principais afluentes. Unpublished M.Sc. Dissertation, Universidade Federal do Paraná, Curitiba, Paraná. 111p.

Odonnell, S. 1997. How parasites can promote the expression of social behaviour in their hosts. Proceedings of The Royal Society of London Series B- Biological Sciences, 264:689-694.

Raibaut, A. \& J. P. Trilles. 1993. The sexuality of parasitic crustaceans. Advanced Pathology, 94:253-261.

Rajkumar M., K. P. K.Vasagam, P. Perumal \& J. P. Trilles 2005. First record of Cymothoa indica (Crustacea, Isopoda, Cymothoidae) infecting the cultured catfish Mystus gulio in India. Diseases of Aquatic Organisms, 65:269-272.

Rice, T., E. Mc Graw, E. K. O'Brien, A. Reverter, D. J. Jackson \& B. M. Degnan. 2006. Parasitic castration by the digenian trematode Allopodocotyle sp alters gene expression in the brain of the host mollusk Haliotis asinina. Febs Letters, 580:37693774 .

Schineider, W. J. 1996. Vitellogenin receptors: oocyte-specific members of the low-density lipoprotein receptor supergene family. International Review of Cytology, 166:103-137.

Snedecor, G. W. \& W. G. Cochran. 1971. Statistical Methods. The Iowa State University Press. Iowa. 593p.

Sorensen, R. E. \& D. J. Minchella. 2001. Snail-trematode life history interactions: past trends and future directions. Parasitology, 123:S3-S18.

Soriguer, M. C., C. Vallespín, C. Gomez-Cama \& J. A. Hernando. 2000. Age, diet, growth and reproduction of a population of Cobistis paludica (de Buen, 1930) in the Palancar stream (southwest of Europe, Spain) (Pisces: Cobitidae). Hydrobiologia, 43:51-58.

Syaghalirwa, N. M., B. Igor, J. M. Bopopi, F. Leprieur \& P. Kestemont. 2005. Effects of sex steroids and their inhibitors on endocrine parameters and gender growth differences in Eurasian perch (Perca fluviatitlis) juveniles. Steroids, 70:80-94.

Thompson, S. N. \& M. Kavaliers, 1994. Physiolgical bases for parasite-induced alteration of host behavior. Parasitology, 109:S119-S138.

Trant, J. M., J. Lehrter, T. Gregory, S. Nunez, \& J. Wunder. 1997. Expression of cytochrome $P 450$ aromatase in the channel catfish, Ictalurus punctatus. Journal of Steroid Biochemistry, 61:393-397.

Vari, R.P. 1992. Systematic of the neotropical Characiform genus Cyphocharax Fowler (Pisces: Ostrariophysi). Smithsonian Contributions to Zoology, (529):1-137p. 
Vazzoler, A. E. A. de. 1996. Biologia da reprodução de peixes teleósteos: Teoria e Prática. Maringa, EDUEM, 169p.

Vizziano, D., F. Le Gag, \& A. Fostier. 1996. Effect of 17 betaestradiol, testosterone, and 11-kestosterone on 17,20 betadihydroxy-4-pregnen-3-one production in rainbow trout testis. Genetic Compendium of Endocrinology, 104:179-188.

Williams, M. A., M. C. Penlington, J. A. King, D. Hoole \& C. Arme. 1998. Ligula intestinalis (Cestoda) infections of roach (Rutiis rutilis) (Cyprinidade): immunochemical investigation into the salmon- and chicken II type gonadotrophin-relaeasing hormone (GnRH) systems in host brains. Acta Parasitologica, 43:332235.

Ziuganov, V. V. 2005. A paradox of parasite prolonging the life of it host Pearl mussel can disable the accelerated senescence program in salmon. Biology Bulletin, 32:360-365.

Received May 2007

Accepted November 2007 